\title{
Czerwiec 1956 w poezji
}

Agnieszka Dębska 


\section{Agnieszka Dębska}

\section{Czerwiec 1956 w poezji}

$\mathrm{W}$

ydarzenia poznańskiego Czerwca rozpoczynają w powojennej historii listę „polskich miesięcy" - dat o znaczeniu symbolicznym. Jednakże, wedle powszechnej opinii, wypadki te nie odbiły się szerokim echem w literaturze: „(...) wszystkiego jest kilka wierszy na ten temat"1. Rzeczywiście, o Poznaniu napisano znacznie mniej, niż na przykład o późniejszych o kilka miesięcy wydarzeniach węgierskiego października ${ }^{2}$. Nie bez wpływu była tu oczywiście zmiana sytuacji politycznej — wiersze o powstaniu węgierskim pisano na fali popaździernikowego otwarcia.

Wśród niewielu utworów będących bezpośrednią reakcją na poznańskie wypadki można odnaleźć także kilka wierszy amatorskich, pisanych przez uczestników tamtych wydarzeń. Niewykluczone, że tego typu tekstów powstało wówczas więcej, jednak brak możliwości ich kolportowania oraz represje wiążące się $z$ uprawianiem działalności poetyckiej na zakazany temat $^{3}$ spowodowały, że nie są one dzisiaj znane. Można jednak sądzić, że było to zjawisko przypominające (oczywiście w dużo mniejszej skali) okolicznościową poezję amatorską powstającą po wydarzeniach Grudnia 1970 czy nawet Sierpnia 1980. Zresztą piosenka napisana przez uczestnika wydarzeń Włodzimierza Marciniaka, którą według relacji świadków śpiewano w więzieniu na Młyńskiej ${ }^{4}$, niezwykle przypomina swoją budową i funkcją

\footnotetext{
' Jacek Trznadel w rozmowie ze Zbigniewem Herbertem, zob.J. Trznadel, Hańba domowa, Warszawa 1997, s. 214. ${ }^{2}$ Dowodzą tego chociażby utwory zebrane w antologii Polscy poeci o wegierskim październiku, wyb., wst. i noty G. Gömöri, Londyn 1996.

${ }^{3}$ Dość przypomnieć los Konrada Doberschuetza, poznańskiego dziennikarza skazanego w 1959 roku na trzy lata więzienia za pisanie nieprawomyślnych wierszy. Ich tematem były między innymi wydarzenia Czerwca 1956. ${ }^{4}$ Por. J. Sandorski, Procesy poznańskie z 1956 roku. Watpliwości, polemiki, klimaty, w: Poznański Czerwiec 1956, red. J. Maciejewski i Z. Trojanowiczowa, Poznań 1990, s. 173. Według niektórych przekazów autorem tego tekstu miał być Bogdan Marianowski.
} 
utwory $\mathrm{z}$ roku 1970. Podobnie jak w ich wypadku, także $\mathrm{i}$ tu silnie zaznaczony podmiot zbiorowy, uczestnik wydarzeń, informuje o wybuchu strajku:

Raz pewnego czwartku strajk my urządzili

Żeby dać nauczkę tej parszywej świni,

rozwoju wydarzeń:

UB do Cyranka dzwoni,

Żeby przysłał pomoc Moskali i broni. (...)

Moskale przybyli w mundurach Polaków,

Żeby pomordować chłopców cegielszczaków,

raz zapowiada zemstę:

Za te wszystkie kary, za te wszystkie zbrodnie

Damy wam po dupie, popękają spodnie ${ }^{5}$.

Relacja o wybuchu strajku, przebiegu wydarzeń i zapowiedź zemsty to stały schemat, który powtarza się w tekstach związanych z Grudniem 1970. Piosenka Marciniaka jest zarazem, podobnie jak wiersze z 1970 roku, przykładem odżywania w czasach współczesnych w specyficznych warunkach — przy braku możliwości swobodnego komunikowania — tradycji twórczości nowiniarskiej.

Interesujące przywołanie w cytowanym utworze „Moskali” (uzasadnione raczej na płaszczyźnie emocjonalnej niż historycznej) w zestawieniu z refrenem:

Wolność, niech żyje wolność, niech żyje nam!

przenosi opisywany konflikt na płaszczyznę narodową. Ten narodowy kontekst obecny jest także, w postaci biało-czerwonej symboliki, w wierszach Konrada Doberschuetza Siostry ze Szpitala Raszei i „Śij spokojnie mój maly chlopczyku”. Również Halina Szymanowicz, pracownica Zakładów Cegielskiego i uczestniczka wydarzeń, interpretuje uliczną demonstrację jako zjednoczenie ludzi dokonujące się w imię ojczyzny:

Poczułam się cząstką tego tłumu,

Nierozerwalnie z nim zlączona

— dziecko z jednej matki łona,

Matki, co zwie się Ojczyzną,

\footnotetext{
s "Obserwator Wielkopolski” $1990 \mathrm{nr}$ 17, s. 9. Informacje o wszystkich wymienionych w artykule utworach zgromadzono na podstawie: W. Albrecht-Szymanowska, Bibliografia Poznańskiego Czerwca 1956, red. Z. Trojanowiczowa, Poznań 1996.

6 „Dzisiaj” 1990 nr 27, s. 6; „Wprost” 1990 nr 5, s. 24 (w artykule A. Cubały Zakazana poezja).
} 
I szłam śpiewając z Nimi

Braćmi i Siostry moimi. ${ }^{7}$

Podczas tego zjednoczenia „tłum” przemienia się w „naród” i staje się świadomy swej siły. Doświadczenie to — zdaniem autorki - wpłynie na jego przyszłość. Czerwiec 1956

(...) był początkiem przemian w Narodzie,

który świadom swej wartości

żądał: „Chleba! Prawdy! Wolności!”

Wydarzenia czerwcowe były też postrzegane jako zobowiązanie, którego należy dotrzymać. Śmierć „Braci «Bandytów»” to w utworze Jacka Małeckiego

Testament spełnionego życia

przedwcześnie $^{8}$

Wypełnić go można jedynie „zdobytą wolnością”. Doberschuetz w wierszu poświęconym Romkowi Strzałkowskiemu — trzynastoletniemu chłopcu zamordowanemu przez funkcjonariuszy UB - pisze:

Twoja misja, Romeczku, skończona

Nasza - rozpoczęta.

$$
\text { („Śpij spokojnie...”) }
$$

Śmierć Romka Strzałkowskiego staje się początkiem pewnej misji także w napisanym dziesięć lat później wierszu Ryszarda Krynickiego:

nic dotąd nie słyszałem o tobie, $\mathrm{i}$

nie myślałem, że będę

coraz dalej i dalej, o sekundy krwi,

o dni i lata, jakie mi zostaną

żeby ukończyć twoją siódmą klasę,

żeby nie bać się żyć,

nie bać się

żyć 9 .

Trwałość pamięci o tych, którzy zginęli, deklaruje też poznański poeta Ryszard Danecki w napisanym w 1956 roku wierszu Poleglym:

7 Czerwiec 1956, „Echo Cegielskiego"1992 nr 26, s. 3.

${ }^{8} 28$ czenvca, "Wyboje" 1956 nr 5, s. 1.

${ }^{9}$ O dni i lata, w: R. Krynicki, Niepodlegli nicości, Warszawa 1988, Niezależna Oficyna Wydawnicza, s. 293. 


\section{(...) pamięć o was co polegliście - trwała i niekrzykliwa... \\ Wokół słońca i własnej osi - \\ Więc w kir nocy dni będą czernieć \\ i co roku maki będzie znosić \\ na wasze groby czerwiec... ${ }^{10}$}

Pamięć jest w cytowanym wierszu czymś bardzo naturalnym, staje się niemal częścią przyrody. Z drugiej strony przyroda może, podobnie jak samo miasto, zostać współuczestnikiem opisywanych wydarzeń. Takk, jak to dzieje się w ekspresjonizującym poemacie Czarmy Czwartek Franciszka Fenikowskiego, również pochodzącym z 1956 roku:

Duszno, duszno jak w prosektorium

$\mathrm{W}$ to czerwcowe, czwartkowe rano. (...)

Szara wieża pięścią z kamienia

Grozi miastu i rośnie przestrach

I narasta groza milczenia

I przycicha ulic orkiestra. (...)

Świecą z murów kul białe rozpryski

Gwiazdy sinych, sczerniałych nieb. (...)

Noc nad miastem zdyszanym wstaje

I jak krzywy nóż wznosi nów ${ }^{11}$.

Jarosław Maciejewski analizując ten poemat zauważa:

Topografia poznańskich ulic, dźwięki, barwy, przestrzeń i ruch tworzą w nim symboliczną, jakby teatralną scenerię dla tego, co się wydarzyło ${ }^{12}$.

Warto zauważyć, że także w innych poetyckich komentarzach do poznańskich wypadków podkreślony zostaje ten teatralny wymiar zdarzeń:

życie

dogania sztukę jakaś rudowłosa

jakiś chlopiec który pochwycił padający sztandar

tramwajarki idące na czele ${ }^{13}$

\footnotetext{
10 „Nurt” 1989 nr 6, s. 7 (w artykule A. Rogalskiego, Poznański szok. Czerwiec 1956).

" „Przewodnik Katolicki” 1988 nr 26, s. 1 i 4 (w artykule J. Maciejewskiego, Poznański czenviec po trzydziestu latach).

12 Ibid., s. 4.

${ }^{13}$ A. K. Waśkiewicz, 27 IV 1956, „Nurt” 1989 nr 2, s. 14.
} 
Dostrzeżenie tej, nader częstej w poetyckim obrazie wydarzeń poznańskiego Czerwca, teatralizacji rzeczywistości pozwala z kolei Sergiuszowi Sternie-Wachowiakowi sformułować wniosek, iż piszący na ten temat artyści „dokonują nieustającego przekładu wypadków na znaki kulturowe" ${ }^{14}$. Niezwykle charakterystycznym przykładem na poparcie tej tezy jest niewątpliwie wiersz Mieczysławy Buczkówny Notatka $z$ wystawy malarstwa francuskiego $w$ Warszawie, w którym „twarze robotników z Poznania” nakładają się na obraz Eugene Delacroix Wolnośc wiodaca lud na barykady ${ }^{15}$.

Wśród „przekładów” i interpretacji, jakim poddawano opisywane wydarzenia, niezwykle częste (zapewne ze względu na polityczną poprawność takiej wykładni) były te, które wpisywały je w kategorie walki klasowej. Intencja taka jest wyraźna w Czarnym Czwartku Fenikowskiego:

Śpiew, śpiew słychać. Zbliża się pochód,

A na czele zły dobosz — głód. (...)

Idą dzieci i robotnice,

Ludzie z przedmieść, z fabrycznych hal (...)

Przed nimi uciekają z miasta „czarne limuzyny”:

W limuzynach jadą frazesy

Limfatyczne, nadęte, blade.

Trzęsie się w trwodze stu lokai

Na poduszkach miękkich limuzyn

Lęk się w oczach wodnistych czai. (...)

W szybach aut drżą jakby w lustrze wody

Twarze tluste pobladłe ze strachu.

Również Kazimiera Iłłakowiczówna „pochylając się” "nad dziejami dwudziestolecia” dostrzega analogię, która sprawia, że ożywiony w jej wierszu bruk zadaje pytanie:

— „Czemu zawsze rządzi inteligent, a do robotników się strzela ?"16

Zaskakujący jest fakt, że tego typu interpretacja występuje także w wierszu poety emigracyjnego. Jan Rostworowski w dramatycznym apelu zwróconym do „ludu fabrycznego”, „mieszkańców przedmieści” (!) wzywa do solidarności z robotnikami Poznania:

${ }^{14}$ S. Sterna-Wachowiak, Symbol i rana. Czerwiec 1956 (1), „Odra” $1991 \mathrm{nr} 6$, s. 33.

15 „Biuletyn Dolnośląski” 1981 nr 6, s. 3.

${ }^{16}$ Rozstrzelano moje serce, „Nurt” 1989 nr 6, s. 7 (w artykule A. Rogalskiego). 
Bo w Poznaniu głód zerwał tłumowi

Gluchy knebel $z$ wychudłego pyska. (...)

Koledzy, bracia w pracy,

Robotnicy całego świata,

Poszarpano wasze sztandary,

Rozpięto wasz sztandar na kratach,

Z waszej świętości zadrwiono. ${ }^{17}$

A zatem w poetyckim obrazie poznańskich wypadków pojawiają się dwie przeciwstawne interpretacje. Wydarzenia czerwcowe są postrzegane bądź jako przejaw walki klasowej, bądź — narodowej. Przy tym — i jest to w jakiś sposób znaczące — interpretacja klasowa pojawia się najczęściej w wierszach pisanych przez zawodowych poetów (wyjątek stanowi tutaj utwór Buczkówny - obecne w jej wierszu „słońce lipca” odsyła, poprzez Warszawiankę, w stronę odniesień narodowych), natomiast w poezji okolicznościowej - w poezji tworzonej przez amatorów, uczestników wydarzeń, dominują dążenia wolnościowe. $\mathrm{Z}$ dwóch równorzędnych haseł Czerwca poeci wybierali raczej „chleb” (tak jak Adam Ważyk, dla którego symbolem poznańskich wypadków stają się „dwa chleby przebite kulami" ${ }^{18}$ ), zaś twórcy wierszy okolicznościowych — „wolność”.

Ta wolnościowa interpretacja jest też wyraźnie obecna podczas obchodów 25 rocznicy wydarzeń poznańskich w 1981 roku. Obchodów, które stały się wielką manifestacją „Solidarności”. W amatorskich wierszach z tego okresu - wierszach, które przynależą do nurtu masowej twórczości okolicznościowej zapoczątkowanej przez Sierpień i będącej wyrazem społecznej potrzeby współuczestniczenia w zachodzących przemianach — wypadki poznańskie powracają jako część tradycji, z której wywodzi się „Solidarność”. Robotnicy z Poznania to ci,

(...) którzy pierwsi

upomnieli się o prawa

i godność prostego człowieka ${ }^{19}$,

którzy

Za Polskę i wolność oddali swe życie $(. . .)^{20}$

Odsłonięty w czerwcu 1981 roku pomnik staje się znakiem jedności narodowej (Marek Tuszewski Pomnik ${ }^{21}$ ) oraz nadziei związanej z aktualną sytuacją:

\footnotetext{
${ }^{17}$ Do was, „Dziennik Polski i Dziennik Żołnierza” (Londyn) 1956 nr 167, s. 2.

${ }^{18}$ Krwawy czerwiec 1956, „Nurt” 1989 nr 6, s. 7 (w artykule A. Rogalskiego).

${ }^{19}$ B. Prawdzic, Tym , którzy pienwsi..., „Nasza Trybuna” $1981 \mathrm{nr} 25$, s. 3.

${ }^{20}$ W. Scisłowski, Dwa krzyże, „Głos Wielkopolski” 1994 nr 148, s. 3.

${ }^{21}$ „Express Poznański” 1990 nr 124, s. 3.
} 
Wstydliwe sprawy $z$ osłonek odarto

i oddzielono fałsze od idei -

aż stanął godnie ten pomnik nad Wartą

tamtej tragedii, dzisiejszej nadziei ${ }^{22}$.

Narodowa interpretacja pojawia się także w utworze Jerzego Grupińskiego. W napisanym przez tego poznańskiego poetę w 1981 wierszu Czerwień Orła utrwalona na fotografii scena z czerwcowych wydarzeń przekształca się w obraz Grottgera Polonia Restituta ${ }^{23}$. W Projekcie na pomnik innego poety z Poznania - Józefa Ratajczaka - powraca, również w kontekście narodowym, postać Romka Strzałkowskiego.

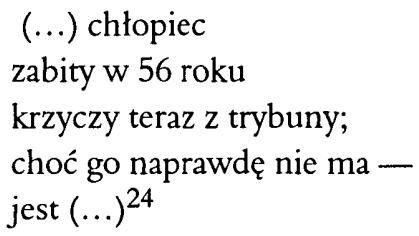

— pisze autor, podkreślając trwałość pamięci o tamtej śmierci. Zresztą o Strzałkowskim nie zapomina także poezja amatorska. Zabity chłopiec opisywany jest tutaj jako bohater narodowy:

Wnuk Piastów, syn tej ziemi -

I odważny, jak naród, który go wydał

I dumny, jak miasto gdzie się urodził

I dojrzały wzburzeniem ojców i braci $(\ldots)^{25}$

Postać Strzałkowskiego pojawia się także w wierszach z okresu stanu wojennego — jako jeszcze jeden symbol martyrologiczny, czasem o wymowie aktualnej. W wierszu Emilii Waśniowskiej przypomnienie śmierci Strzałkowskiego staje się okazją do wyrażenia protestu przeciwko zabijaniu dzieci ${ }^{26}$. W 1983 roku taki protest mógł być odczytany jako aluzja do współczesnych wydarzeń. Zaś w napisanym w styczniu 1982 wierszu Strzatkowski Roman Bąk wkłada w usta umierającego chłopca zdanie:

$$
\begin{aligned}
& \text { nie umiem mówić } \\
& \text { nie znam już żadnego znaku }(\ldots)^{27}
\end{aligned}
$$

To stwierdzenie niezwykle znamienne dla utworu pochodzącego z okresu stanu wojennego, który był - wedle obiegowych metafor — odebraniem możliwości mówienia.

\footnotetext{
${ }^{22}$ W. Degler, $W$ rocznic̨ Czerwca, „Express Poznański” 1981 nr 122, s. 6.

${ }^{23}$ J. Grupiński, Album Wielkopolski, Poznań 1981, s. 11. Jest to zarazem kolejny przykład „uznakowienia” czerwcowych wydarzeń.

${ }^{24}$ „Nurt” $1981 \mathrm{nr} 6$, s. 5.

${ }^{25}$ M. Tuszewski, Pamięci Romka Strzatkowskiego, „Dzisiaj” 1990 nr 123, s. 4.

${ }^{26}$ Poznański chlopiec, w: E. Waśniowska, Przychylic ziemi, Warszawa 1983, s. 24.

${ }^{27}$ R. Bąk, Którzy by mogli powiedzieć, Poznań 1991, s. 12.
} 
Przemiany poetyckiego obrazu poznańskich wypadków można zatem interpretować także w kategoriach „odebrania” i „przywrócenia” mowy. W 1981 roku obchodzenie rocznicy poznańskich wydarzeń stało się możliwe:

Gdy ludziom pieczęć milczenia z ust zdjęto $(. . .)^{28}$

Nurt poezji amatorskiej, który narodził się po „przywróceniu mowy”29 w Sierpniu 1980, może być też postrzegany jako kontynuacja tendencji wolnościowych zapoczątkowanych przez utwory nawiązujące do Czerwca 1956 . W ten sposób pojawienie się poezji sierpniowej interpretował Marian Grześczak, który w odniesieniu do wypadków poznańskich pisał:

Wtedy właśnie narodził się czysty moralnie nurt literatury polskiej, lecz zaraz skrył się pod ziemię, żeby dziś, po wielu zakolach, wypłynąć na powierzchnię już nie strumyczkiem strachliwym, ale szeroką rzeką ${ }^{30}$.

To zdanie napisane w 1981 roku jest swoistym znakiem czasu - autor nie podejrzewał zapewne, że „szeroka rzeka” stanie się już wkrótce na powrót „rzeką podziemną”.

Zanim jednak w 1980 roku „zdjęto” „pieczęć milczenia”, poeci próbujący opisać poznańskie wypadki skarżyli się na niemożność mówienia:

O kulturze... Próba wzniosłych syntez,

Artystycznych intuicji zgranie...

Ja nie moge... Ani kwarty, ani kwinty.

Rozstrzelano moje serce w Poznaniu

— pisała Itłakowiczówna ${ }^{31}$. Podobnie jest w wierszu Adama Ważyka:

(...) słowa już się nie liczą

tyle ich poległo

czerwiec się kończy

jak ten wiersz

milczeniem $^{32}$

Jest to jednak również wynik dewaluacji słowa, która była niezwykle silnie odczuwana w 1956 roku. Mówi o tym także między innymi pochodzący z tego okresu wiersz Wiktora Woroszylskiego „Nasze stowa największe...":

\footnotetext{
${ }^{28}$ W. Degler, $W$ rocznicę Czerwca, op. cit.

${ }^{29} \mathrm{~W}$ podobnych kategoriach o poezji sierpniowej - jako o „odnowieniu języka” — pisała Danuta Dąbrowska w książce Okolicznościowa poezja polityczna w Polsce w latach 1980-1990, Szczecin 1998 (por. s. 45-47).

${ }^{30}$ Moja obsesja. Rzecz gustu, „Życie Warszawy” 1981 nr 142, s. 6.

${ }^{31}$ Rozstrzelano moje serce, op. cit.

${ }^{32}$ Krwauy czerwiec 1956, op. cit.
} 
Nasze słowa największe najświętsze jak chorągwie rozdarte na wietrze Nasze słowa gromy bez echa Świst powietrza w rozdartych miechach Strun rdzewienie i szept zaniechaj ${ }^{33}$

Rok wcześniej Jerzy Zagórski zadawał pytanie:

Czy zmieni $\mathrm{z}$ kłamstwem w historii wartę nie sfałszowane słowo otwarte ${ }^{34}$.

Wydaje się, że zarysowane tu przemiany poetyckiego obrazu poznańskich wydarzeń można traktować jako próbę odpowiedzi na to pytanie. Jest to zarazem niewielki przyczynek do dziejów swoistej „walki o oddech” poezji polskiej, walki o wolne słowo.

\footnotetext{
${ }^{33}$ W. Woroszylski, Podróż. Wiersze z różnych lat 1955-1985, Warszawa 1986, s. 20.

${ }^{34} \mathrm{~J}$. Zagórski, „Czy tylko glucha rozpacz w czlowieku”, w: idem, Nie mrużmy powiek, Warszawa 1985, „Przedświt. Warszawska Niezalezna Oficyna Poetów i Malarzy", s. 8.
} 